\title{
Hubungan Tingkat Pengetahuan dan Sikap dengan Perilaku Mengatasi Ketidaknyamanan pada Masa Klimakterium
}

\author{
Niken Purbowati ${ }^{*}$ Wa ode Hajrah, Novia Nuraini \\ Jurusan Kebidanan, Poltekkes Kemenkes Jakarta III \\ *Email Korespondensi: purbowatiniken@gmail.com
}

Article Info

Article history:

Submitted: 2019-11-01

Accepted: 2019-12-23

Published: 2019-12-30

Keywords:

Knowledge; Attitude;

Behavior; Climacterium

Discomfort

Climacteric is a transitional period from the reproductive phase to the old age phase (senium). Climacteric period $40-85 \%$ of women have complaints both physically and psychologically. The differences in knowledge based on personal backgrounds cause the attitude of each individual is different in overcoming the inconvenience of the climacteric phase. This study aims to determine the relationship between the level of knowledge and attitudes towards overcoming discomfort during the climacteric phase. It was a descriptive-analytic research method using a cross-sectional research design. The research sample was 81 respondents. Sampling was stratified random sampling, that is, samples taken per work area randomly. Statistical tests use logistic regression. The results of 81 mothers showed that the proportion of mothers with good knowledge was $87.9 \%$, compared to a lack of knowledge as many as $20.8 \%$. There was a significant relationship between knowledge and behavior to overcome climacteric discomfort ( $p=0.029 ; \mathrm{Cl} 195 \%=1.2-27.1)$. Mothers with good knowledge had a 5.7 times higher chance to behave well in dealing with discomfort during climacteric times, compared to mothers with less knowledge after being controlled by attitude, family roles, and health worker roles.

\section{ABSTRAK}

Kata Kunci:

Pengetahuan; Sikap;

Perilaku;

Ketidaknyamanan

Klimakterium
Klimakterium merupakan periode peralihan dari fase reproduksi menuju fase usia tua (senium). Masa klimakterium 40-85\% wanita mempunyai keluhan baik fisik maupun psikologis. Adanya perbedaan pengetahuan sesuai dengan latar belakang individu, sehingga sikap masing-masing individu berbeda dalam mengatasi ketidaknyamanan masa klimakterium. Penelitian ini bertujuan untuk mengetahui hubungan tingkat pengetahuan dan sikap terhadap perilaku mengatasi ketidaknyamanan pada masa klimakterium. Metode penelitian deskriftif analitik menggunakan desain penelitian Cross sectional. Sampel penelitian sebanyak sampel 81 responden, Pengambilan sampel secara stratified random sampling yaitu sampel yang diambil per wilayah kerja secara acak. Uji statistik menggunakan regresi logistik. Hasil penelitian dari 81 ibu menunjukkan proporsi ibu dengan pengetahuan baik sebesar $87,9 \%$, dibandingkan pengetahuan kurang yaitu $20,8 \%$. Terdapat hubungan yang bermakna antara pengetahuan dengan perilaku mengatasi ketidaknyamanan masa klimakterium ( $p=0,029$; $C \mid 95 \%=1,2-27,1)$. Ibu yang pengetahuannya baik berpeluang 5,7 kali lebih tinggi untuk berperilaku baik dalam mengatasi ketidaknyamanan pada masa klimakterium, dibandingkan dengan ibu berpengetahuan kurang setelah dikontrol variabel sikap, peran keluarga dan peran petugas kesehatan. 


\section{PENDAHULUAN}

Keberhasilan pembangunan nasional dibidang kesehatan salah satunya adalah menurunnya angka kelahiran dan meningkatnya umur harapan hidup (life expectancy). Hal ini berdampak bertambahnya $10-11 \%$ proporsi lansia atau 30 juta jiwa pada 2020. Diperkirakan pada 2020 jumlah wanita dalam usia klimakterium atau menopause terus bertambah jumlahnya mencapai 30,3 juta jiwa. ${ }^{1}$ Hal ini perlu mendapatkan perhatian karena terjadi perubahan kondisi fisik, psikologis yang dapat menimbulkan berbagai keluhan kesehatan. Menopause berarti berhentinya menstruasi dan berakhirnya kesuburan. Usia alami menopause adalah 45-55 tahun dan penyebab utamanya adalah penghentian aktivitas alami ovarium. ${ }^{2}$

Klimakterium merupakan periode peralihan dari fase reproduksi menuju fase usia tua (senium) yang terjadi akibat menurunnya fungsi generatif ataupun endokrinologik dari ovarium. Penurunan produksi hormon estrogen menimbulkan berbagai keluhan pada seorang wanita, sedangkan penurunan fertilitas sangat bergantung pada usia wanita tersebut. Fertilitas wanita pada usia 35-39 tahun hanya tinggal $60 \%$, sedangkan laki-laki masih tetap tinggi, yaitu 95\%. Pada usia 45-49 tahun fertilitas wanita tinggal $5 \%$ saja dan pada laki-laki mencapai $80 \%{ }^{3}$ Pada masa klimakterium sebesar $40-85 \%$ dari semua wanita mempunyai keluhan baik fisik maupun psikologis. Beberapa wanita menganggap ketidaknyamanan fisik maupun psikologis hal yang biasa, namun sebagian wanita menganggap masalah serta merugikan dirinya. ${ }^{4}$

Pengetahuan yang baik tentang menopause akan membantu wanita klimakterium untuk dapat menyiapkan diri, dan dapat bersikap serta berperilaku tepat dalam melakukan pencegahan maupun mengatasi ketidaknyamanan yang muncul pada masa klimakterium. Berbagai ketidaknyamanan yang dirasakan pada masa klimakterium, membuat berbagai tanggapan dan penilaian yang berbeda-beda pada tiap wanita. Adanya perbedaan pengetahuan sesuai dengan latar belakang individu, sehingga sikap masing-masing individu berbeda dalam mengatasi ketidaknyamanan masa klimakterium. ${ }^{5}$ Masyarakat di daerah pedesaan yang penuh dengan kesibukan setelah senja atau malam dengan sendirinya sudah tertidur, sehingga tidak sempat memperhatikan diri tentang ketidaknyamanan berkaitan masalah klimakterium. ${ }^{4}$

Hasil penelitian Apriyanti, menyatakan bahwa sikap wanita klimakterium dalam menghadapi dan mengatasi keluhan masa menopause adalah positif. Pendidikan, informasi yang didapat dari petugas kesehatan maupun media massa memberikan pengaruh terhadap pembentukan sikap seseorang. ${ }^{6}$ Diperkuat dengan penelitian Ismiyati, menyatakan bahwa ada hubungan antara tingkat pengetahuan dengan kesiapan menghadapi menopause, ini berhubungan dengan kesiapan ibu dalam mengatasi ketidaknyamanan yang timbul selama periode pramenopause ${ }^{(6)}{ }^{7}$

Berdasarkan hasil studi pendahuluan yang dilakukan pada Desember 2015 di wilayah kerja Puskesmas Kecamatan Sawah Besar Jakarta Pusat, dilakukan wawancara pada 10 orang ibu yang berusia antara 40 tahun sampai dengan 50 tahun, mereka telah memasuki masa klimakterium. Enam dari sepuluh ibu merasakan haid mulai tidak teratur, takut ada kelainan dalam rahimnya, merasa panas pada wajah dan tubuh di malam hari, jantung kadang berdebar, tidak bergairah untuk berhubungan intim dengan suami, dan sulit tidur pada malam hari. Empat ibu mengatakan haid masih teratur, tetapi jumlahnya kadang banyak atau sedikit, mulai sulit tidur di malam hari. Mereka juga mengatakan cepat letih, kadang nyeri kepala, nyeri sendi dan otot. Enam dari sepuluh ibu tersebut, mengatakan tidak tahu bagaimana cara mengatasi 
ketidaknyamanan tersebut, mereka mengatakan apakah perlu memeriksakan diri, perlukah minum obat atau jamu. Empat ibu lainnya mengatakan pasrah dengan kondisi tersebut, karena menurutnya wajar terjadi menjelang akan menopause. Penelitian ini bertujuan untuk mengetahui hubungan antara pengetahuan dan sikap dengan perilaku mengatasi ketidaknyamanan pada masa klimakterium

\section{METODE PENELITIAN}

Penelitian ini menggunakan desain survei analitik dengan pendekatan potong lintang (Cross Sectional). Data untuk variabel dependen dan variabel independen didapatkan pada waktu sesaat dan bersamaan. Populasi terjangkau adalah seluruh ibu pramenopause (40 tahun - 48 tahun), usia Perimenopause (49-55 tahun) di wilayah kerja Puskesmas Kecamatan Sawah Besar Jakarta Pusat pada periode penelitian April sampai dengan September 2016. Populasi terjangkau sebanyak 170 ibu masa klimakterium.

Pengambilan sampel secara stratified random sampling yaitu teknik pengambilan sampel dari anggota populasi secara acak dan berstrata secara proporsional berdasarkan usia masa klimakterium yang berada di 5 kelurahan yaitu Kelurahan Mangga Dua Selatan, Kelurahan Pasar Baru, Kelurahan Kartini, Kelurahan Karang Anyar dan Kelurahan Gunung Sahari Utara. Selanjutnya dari 5 kelurahan tersebut dipilih secara random 12 RW dari 46 RW keseluruhan yang ada di Wilayah Kecamatan Sawah Besar. Dari 170 populasi terjangkau didapat sampel 81 responden, akan diambil secara proporsional ibu yang memasuki masa klimakterium dari 12 RW. Penelitian ini menggunakan data primer yang diperoleh langsung dari responden dengan melakukan wawancara terstruktur menggunakan kuesioner, pendataan oleh kader yang disinkronkan dengan data jumlah wanita usia klimakterium yang ada di setiap RW. Analisis Bivariat Uji statistik yang digunakan untuk penelitian ini adalah uji Chi Square dengan tingkat kemaknaan $p<0,05$. Analsis multivariat yang digunakan dalam penelitian ini yaitu regresi logistik.

\section{HASIL PENELITIAN}

\section{Analisis Univariat}

Distribusi Frekuensi Pengetahuan, Sikap Ibu terhadap Perilaku Mengatasi Ketidaknyamanan Pada Masa Klimakterium

Tabel 1 Karakteristik Responden Pengetahuan, Sikap Ibu terhadap Perilaku Mengatasi Ketidaknyamanan pada Masa Klimakterium

\begin{tabular}{lcc}
\hline Variabel Penelitian & Frekuensi (n) & Persentase (\%) \\
\hline Perilaku & & \\
$\quad$ Perilaku tidak baik & 42 & 51,9 \\
$\quad$ Perilaku baik & 39 & 48,1 \\
Umur & & \\
$\quad$ Umur Pramenopause & 26 & 32,1 \\
$\quad$ Umur Perimenopause & 55 & 67,9 \\
Pendidikan & 37 & 45,7 \\
$\quad$ Pendidikan Dasar & 33 & 40,7 \\
$\quad$ Pendidikan Menengah & 11 & 13,6 \\
$\quad$ Pendidikan Tinggi & & 53,1 \\
Pekerjaan & 43 & 46,9 \\
$\quad$ Tidak bekerja & 38 & \\
$\quad$ Bekerja & &
\end{tabular}




\begin{tabular}{lcc}
\hline Variabel Penelitian & Frekuensi (n) & Persentase (\%) \\
\hline Pengetahuan & 48 & \\
Pengetahuan kurang & 33 & 59,3 \\
Pengetahuan baik & 30,7 \\
\hline
\end{tabular}

\section{Analisis Bivariat}

Tabel 2. Hubungan Umur, Pendidikan, Pekerjaan, Pera Petugas Kesehatan, Peran Keluarga, Pengetahuan, dan Sikap dengan Perilaku Mengatasi Ketidaknyamanan Masa Klimakterium di Puskesmas Kec. Sawah Besar

\begin{tabular}{|c|c|c|c|c|c|c|c|c|c|}
\hline \multirow[t]{3}{*}{ Variabel } & & \multicolumn{4}{|c|}{ Perilaku } & \multirow{2}{*}{\multicolumn{2}{|c|}{ Total }} & \multirow[t]{3}{*}{ OR } & \multirow{3}{*}{ Nilai $p$} \\
\hline & & \multicolumn{2}{|c|}{ Tidak baik } & \multicolumn{2}{|c|}{ baik } & & & & \\
\hline & & $\mathbf{n}$ & $\%$ & $\mathbf{n}$ & $\%$ & $\mathbf{n}$ & $\%$ & & \\
\hline \multirow[t]{2}{*}{ Umur } & Pramenopause & 12 & 46,2 & 14 & 53,8 & 26 & 100 & 0,7 & 0,640 \\
\hline & Perimenopause & 30 & 54,5 & 25 & 45,5 & 55 & 100 & & \\
\hline \multirow[t]{3}{*}{ Pendidikan } & Dasar & 26 & 70,3 & 11 & 29,7 & 37 & 100 & & 0,0001 \\
\hline & Menengah & 16 & 48,5 & 17 & 51,5 & 33 & 100 & 2,5 & \\
\hline & Tinggi & 0 & 0 & 11 & 100 & 11 & 100 & 3,8 & \\
\hline \multirow{2}{*}{ Pekerjaan } & Tidak bekerja & 28 & 65,1 & 15 & 34,9 & 43 & 100 & 3,2 & 0,020 \\
\hline & Bekerja & 14 & 36,8 & 24 & 63,2 & 38 & 100 & & \\
\hline Peran Petugas & Tidak berperan & 34 & 70,8 & 14 & 29,2 & 48 & 100 & 7,6 & 0,0001 \\
\hline Kesehatan & Peran aktif & 8 & 24,2 & 25 & 75,8 & 33 & 100 & & \\
\hline Peran & Tidak berperan & 36 & 75,0 & 12 & 25,0 & 48 & 100 & 13,5 & 0,0001 \\
\hline Keluarga & Peran aktif & 6 & 18,2 & 27 & 81,8 & 33 & 100 & & \\
\hline \multirow[t]{2}{*}{ Pengetahuan } & Kurang & 38 & 79,2 & 10 & 20,8 & 48 & 100 & 27,6 & 0,0001 \\
\hline & Baik & 4 & 12,1 & 29 & 87,9 & 33 & 100 & & \\
\hline \multirow[t]{2}{*}{ Sikap } & Tidak baik & 35 & 76,1 & 11 & 23,9 & 46 & 100 & 12,7 & 0,0001 \\
\hline & Baik & 7 & 20,0 & 28 & 80,0 & 35 & 100 & & \\
\hline
\end{tabular}

Uji Statistik Chi Square

\section{Analisis Multivariat}

Tabel 3. Analisis Multivariat tentang Perilaku Mengatasi Ketidaknyamanan Masa Klimakterium di Puskesmas Kec. Sawah Besar

\begin{tabular}{lccccc}
\hline \multicolumn{1}{c}{ Variabel } & $\begin{array}{c}\text { Koefisien } \\
\text { B }\end{array}$ & P & Exp (B) & \multicolumn{2}{c}{ 95\% C.I. for Exp(B) } \\
\cline { 5 - 6 } & & & & Lower & Upper \\
\hline Peran Nakes & 0,854 & 0,240 & 2,349 & 0,564 & 9,773 \\
Peran Keluarga & 1,399 & 0,056 & 4,051 & 0,964 & 17,028 \\
Pengetahuan & 1,742 & 0,029 & 5,707 & 1,201 & 27,124 \\
Sikap & 1,436 & 0,050 & 4,203 & 1,000 & 17,656 \\
Uji Regresi Logistik Ganda & & & & &
\end{tabular}

\section{PEMBAHASAN}

\section{Hubungan Pengetahuan dengan Perilaku Mengatasi Ketidaknyamanan Masa Klimakterium}

Perilaku baik yang dimaksud dalam penelitian ini adalah ibu yang mampu mengatasi atau mengurangi ketidaknyamanan yang dirasakan pada masa klimakterium yaitu masa menjelang terjadinya menopause. Perilaku individu atau kelompok dipengaruhi oleh tiga faktor, mencakup organizational actions dalam hubungannya dengan lingkungan, masing-masing mempunyai tipe yang berbeda dalam mempengaruhi perilaku. Ketiga faktor tersebut yaitu Faktor Predisposisi 
(predisposing factor), Faktor Pemungkin (enabling factor), dan Faktor Penguat (reinforcing factor). ${ }^{8}$

Hasil uji Chi Square menunjukkan bahwa hubungan yang bermakna antara pengetahuan dengan perilaku mengatasi ketidaknyamanan masa klimakterium $(p=0,0001)$. Proporsi ibu dengan pengetahuan baik lebih banyak yang berperilaku baik sebesar $87,9 \%$, dibandingkan ibu yang pengetahuan kurang yaitu $20,8 \%$. Ibu dengan pengetahuan baik memiliki peluang $(O R=27,55)$ kali berperilaku baik mengatasi ketidaknyamanan masa klimakterium dibanding ibu yang pengetahuan kurang.

Hasil uji regresi logistik menunjukkan proporsi ibu dengan pengetahuan baik lebih banyak yang berperilaku baik sebesar $87,9 \%$, dibandingkan ibu yang pengetahuan kurang yaitu $20,8 \%$. Hasil analisis regresi logistik pengetahuan mempunyai hubungan bermakna dengan perilaku mengatasi ketidaknyamanan pada masa klimakterium $(p=0,029)$. Ibu yang pengetahuannya baik akan mempunyai peluang berperilaku baik dalam mengatasi ketidaknyamanan pada masa klimakterium sebesar 5,7 kali lebih tinggi, dibandingkan ibu yang pengetahuannya kurang setelah dikontrol variabel sikap, peran keluarga dan peran petugas kesehatan. Pengetahuan ibu yang lebih baik, akan berpeluang dalam mengatasi ketidaknyamanan yang muncul pada masa klimakterium.

Pengetahuan merupakan hasil stimulasi informasi yang diperhatikan dan diingat. Informasi dapat diperoleh baik melalui pendidikan formal maupun pendidikan nonformal, percakapan harian, mendengar maupun menonton media komunikasi verbal dan nonverbal, serta pengalaman hidup lainnya. ${ }^{8}$

Hasil penelitian ini sama dengan penelitian Marni menyatakan bahwa responden dengan pengetahuan baik dalam menghadapi ketidaknyamanan masa klimakterium sebesar $23,3 \%$, sedangkan pengetahuan yang cukup sebesar $60 \%$, dengan latar belakang pendidikan SMP. Ada hubungan antara pengetahuan dengan kesiapan menghadapi ketidaknyamanan masa klimakterium. ${ }^{9}$

Hasil penelitian ini sesuai dengan penelitian Batan di Manado menyatakan bahwa pengetahuan ibu kategori baik tentang tata cara mengurangi keluhan menopause sebesar $60 \%$, pengetahuan tidak baik sebesar $40 \%$. Pengetahuan berhubungan dengan cara mengurangi keluhan menopause. ${ }^{10}$

Hasil peneltian Prasetya, dkk pada tahun 2012 menunjukkan bahwa pengetahuan tentang menopause pada sebagian besar subyek masih terbatas. ${ }^{11}$ Hal ini mengindikasikan bahwa diseminasi menopause belum merata di kalangan perempuan paruh baya. Banyaknya informasi yang keliru tentang menopause tentu bisa membentuk persepsi negatif tentang menopause dan mereka tidak dapat mengatasi keluhan-keluhan yang timbul. Faktor keluarga terdekat, seperti ibu dan kerabat perempuan, berperan besar dalam membentuk persepsi tentang menopause dan cara mengatasi ketidaknyamanan masa klimakterium. Pasangan, dalam hal ini suami, memiliki peran besar dalam menjalani kehidupan masa klimakterium. Peran suami dibutuhkan dalam hal membantu mengatasi ketidaknyamanan masa klimakterium, memberi perhatian bila mengalami keluhan dan mengantar ke fasilitas kesehatan untuk berkonsultasi dengan petugas kesehatan.

Hasil penelitian Nurwahyuni menyatakan bahwa kurangnya pemahaman responden tentang gejala menopause, keluhan-keluhan yang timbul pada masa klimakterium dianggap hal lumrah. ${ }^{12}$ Pengetahuan responden tentang masa klimakterium hanya sebatas tahu, keluhan-keluhan yang dirasakan menjelang menopause dianggap proses menua. Pengetahuan mereka untuk mengatasi 
ketidaknyamanan masa klimakterium dengan berolahraga dan hidup lebih religius. Pemahaman tentang masa klimakterium yaitu menopause ini tentunya tidak lepas dari bagaimana mereka mendapatkan informasi tentang masa klimakterium itu sendiri. Mereka tidak mendapatkan informasi dari petugas kesehatan tentang masa klimakterium.

\section{Hubungan Sikap dengan Perilaku Mengatasi Ketidaknyamanan Masa Klimakterium}

Sikap menurut Notoatmodjo merupakan reaksi atau respons yang masih tertutup dari seseorang terhadap suatu stimulus atau objek. Manifestasi sikap itu tidak dapat langsung dilihat, tetapi hanya dapat ditafsirkan terlebih dahulu dari perilaku yang tertutup. Sikap secara nyata menunjukkan konotasi adanya kesesuaian reaksi terhadap stimulus tertentu yang dalam kehidupan sehari-hari merupakan reaksi yang bersifat emosional terhadap stimulus sosial. ${ }^{13}$

Pendidikan memberikan pengaruh terhadap pembentukan sikap seseorang, dengan pendidikan yang lebih tinggi akan meningkatkan sikap wanita klimakterium menjadi lebih baik. Menurut Azwar menyatakan bahwa lembaga pendidikan sebagai suatu sistem mempunyai pengaruh dalam pembentukan sikap dikarenakan lembaga pendidikan meletakkan dasar pengertian dan konsep moral dalam diri individu. ${ }^{14}$ Pesan-pesan sugestif yang dibawa oleh informasi media massa, apabila cukup kuat, akan memberi dasar afektif dalam menilai sesuatu hal sehingga terbentuklah arah sikap tertentu.

Hasil uji Chi Square menunjukkan bahwa ada hubungan yang bermakna antara sikap dengan perilaku mengatasi ketidaknyamanan masa klimakterium $(p=0,0001)$. Proporsi ibu dengan sikap baik lebih banyak yang berperilaku baik sebesar $80,0 \%$, dibandingkan ibu yang sikap tidak baik yaitu $23,9 \%$. Ibu dengan sikap baik memiliki peluang 12,7 kali berperilaku baik mengatasi ketidaknyamanan masa klimakterium dibanding ibu yang sikap tidak baik.

Sedangkan hasil uji regresi logistic menunjukkan bahwa proporsi ibu dengan sikap baik lebih banyak yang berperilaku baik dalam mengatasi ketidaknyamanan masa klimakterium sebesar $80,0 \%$, dibandingkan ibu yang sikap tidak baik yaitu $23,9 \%$. Hasil analisis chi square, ada hubungan antara sikap dengan perilaku mengatasi ketidaknyamanan masa klimakterium. Sikap, peran keluarga dan peran petugas kesehatan merupakan variabel pengontrol (konfounding) untuk pengetahuan.

Hasil penelitian ini sesuai dengan Barrett-Connor dan Elizabeth menyatakan bahwa ada hubungan yang signifikan antara sikap ibu usia 45-50 tahun dengan kecemasan menghadapi menopause. Sikap disini yaitu sikap positif dan sikap negatif dalam menghadapi menopause. ${ }^{15}$

Hasil penelitian Apriyanti menunjukkan bahwa sikap ibu klimakterium dalam menghadapi gangguan haid tidak teratur adalah positif sebesar $65,18 \%$. Sikap ibu klimakterium dalam menghadapi hot flushes yang timbul malam hari adalah positif, sebesar $61,01 \%$. Sikap ibu dalam menghadapi keringat banyak pada malam hari adalah positif, sebesar $60,27 \%$. Sikap ibu klimakterium dalam menghadapi masa menopause adalah positif, sebesar $61,91 \%{ }^{6}$

Hasil penelitian Jurgenson et al. menyatakan bahwa wanita masa klimakterium memilliki sikap yang berbeda-beda dalam menghadapi dan mengatasi keluhan yang timbul menjelang menopause. Sikap yang negatif dalam menghadapi masa menopause berhubungan dengan umur. Wanita dengan umur di atas 40 tahun ada yang memiliki sikap positif dan sikap negatif terhadap masa 
klimakterium. Sikap negatif pada wanita klimakterium antara lain ketakutan akan tanda dan gejala yang timbul menjelang menopause, beranggapan itu adalah penyakit, terutama masalah hot flushes, perubahan mood, kulit kendur, serta penuaan. Adanya sikap negatif ini karena kurangnya informasi tentang menopause dan cara mengatasi ketidaknyamanan yang timbul. ${ }^{16}$

Hasil penelitian Prasetya, dkk menunjukkan bahwa pemahaman tentang masa klimakterium subyek penelitian yang didapat dari informasi keluarga, teman sebaya, petugas kesehatan, majalah, internet dan sekolah mempengaruhi dalam bersikap menghadapi menopause dan mengatasi ketidaknyamanan yang timbul menjelang menopause terjadi. ${ }^{11}$ Pengalaman menopause dari keluarga seperti ibunya, uwak ataupun saudara sepupu ternyata mempengaruhi sikap ibu yang memasuki masa klimakterium. Tidak hanya pengalaman, aktivitas sehari-hari dan kegiatan religius dapat mempengaruhi sikap ibu yang memasuki masa klimakterium. Mereka mengakui mind set (pola pikir) yang positif tentang menopause sangat membantunya dalam mengatasi ketidaknyamanan masa klimakterium.

Menurut Azwar komponen sikap ada 3 yaitu komponen kognitif, afektif, dan psikomotor. Komponen kognitif sikap adalah aspek pengetahuan dari objek, sedangkan komponen afektif adalah perasaan positif atau negatif yang berhubungan dengan pengetahuan yang dimiliki individu(13). Sikap ibu dalam menghadapi dan mengatasi ketidaknyamanan yang timbul pada masa klimakterium dipengaruhi oleh faktor-faktor seperti kondisi sosioekonomi, pendidikan, dukungan keluarga, dukungan petugas kesehatan dalam memberikan informasi tentang menopause. Kondisi sosio-ekonomi dan dukungan keluarga juga berpengaruh terhadap psikologis seorang ibu yang memasuki masa klimakterium. ${ }^{16}$

\section{SIMPULAN DAN SARAN}

Hasil penelitian ini menunjukkan proporsi ibu dengan pengetahuan baik lebih banyak yang berperilaku baik, dibandingkan ibu yang pengetahuan kurang. Pengetahuan mempunyai hubungan bermakna dengan perilaku mengatasi ketidaknyamanan pada masa klimakterium. Ibu yang pengetahuannya baik akan mempunyai peluang berperilaku baik dalam mengatasi ketidaknyamanan pada masa klimakterium sebesar 5,7 kali lebih tinggi, dibandingkan ibu yang pengetahuannya kurang setelah dikontrol variabel sikap, peran keluarga, dan peran petugas kesehatan. Penelitian ini menyarankan agar bidan puskesmas lebih proaktif dalam memberikan edukasi kepada ibu pramenopause.

\section{UCAPAN TERIMA KASIH}

Penulis menyampaikan terima kasih kepada Kepala Puskesmas Kecamatan Sawah Besar yang telah memberikan izin meneliti serta seluruh responden yang telah berpartisipasi dengan baik sehingga penelitian ini bisa terlaksana.

\section{DAFTAR PUSTAKA}

1. Badan Pusat Statistik. Laporan Demografi. Jakarta; 2010.

2. Taherpour M, Sefidi F, Afsharinia S, Hamissi JH. Menopause knowledge and attitude among Iranian women. J Med Life. 2015;8(Spec Iss 2):72-6.

3. Baziad A. Menopause Dan Andropause Dan Terapi Sulih Hormon (TSH). Jakarta: Yayasan Bina Pustaka Sarwono Prawirohardjo; 2013. 
4. Manuaba IBS. Memahami Kesehatan Reproduksi Wanita. Jakarta: ECG; 2011.

5. Indriani N. Perbedaan sikap wanita dalam menghadapi masa klimakterium dilihat dari pengetahuan tentang menopause di Desa Kampung Islam Kusamba Kecamatan Dawan Kabupaten Klungkung Bali. Universitas Islam Negeri Maulana Malik Ibrahim; 2007.

6. Apriyanti E, Sumantri, Tanjung AS. Attitudes Of Klimakterium's Women In Dealing Menopause Perioed At Jimus Village Polanharjo District Klaten Regency. Klaten. J Ilmu Kesehat. 2012;IV(2).

7. Ismiyati A. Hubungan Tingkat Pengetahuan Tentang Menopause Dengan Kesiapan Menghadapi Menopause Pada Ibu Premenopause Di Perumahan Sewon Asri Yogyakarta. Vol. 9. Universitas Sebelas Maret; 2010.

8. Green LW, Kreuter MW. Health Promotion Planning : an Educational and Environmental Approach. Mayfield Pub. Co; 1991. 506 p.

9. Karo MB. Hubungan Tingkat Pengetahuan Tentang Menopause dan Premenopause di RT 004 RW 005 Kelurahan Sepanjang Jaya Kota Bekasi. Sekolah Tinggi Kesehatan Medistra; 2011.

10. Batan IS, Mewengkang M, Tendean HMM. Pengetahuan Ibu Tentang Menopause Di Poliklinik Blu Rsu Prof. Dr. R. D. Kandou Manado. J e-Biomedik. 2013;1(1):364-70.

11. Prasetya MR, Firmiana ME, Imawati R. Peran Religiusitas Mengatasi Kecemasan Masa Menopause. J Al-AZHAR Indones SERI Hum [Internet]. 2012 Apr 26;1(3):145. Available from: https://jurnal.uai.ac.id/index.php/SH/article/view/64

12. Nurwahyun, Ngatimin R, Arsin AA. Perilaku Wanita Menopause Di Wilayah Kerja Puskesmas Kolaka Kabupaten Kolaka Tahun 2012. Universitas Hasanuddin; 2012.

13. Notoatmodjo S. Promosi Kesehatan dan Perilaku Kesehatan. Revisi 201. Jakarta: Rineka Cipta; 2012.

14. Azwar S. Sikap Manusia Teori dan Pengukurannya. 2nd ed. Yogjakarta: Pustaka Pelajar; 2011.

15. Barrett-Connor E. Menopause, Atherosclerosis, and Coronary Artery Disease. Curr Opin Pharmacol [Internet]. $2013 \quad$ Apr;13(2):186-91. Available from: https://linkinghub.elsevier.com/retrieve/pii/S147148921300009X

16. Jurgenson JR, Jones EK, Haynes E, Green C, Thompson SC. Exploring Australian Aboriginal Women's experiences of menopause: a descriptive study. BMC Womens Health [Internet]. $2014 \quad$ Dec 20;14(1):47. Available from: http://bmcwomenshealth.biomedcentral.com/articles/10.1186/1472-6874-14-47 